International Journal of English Literature and Social Sciences
Vol-7, Issue-1; Jan-Feb, 2022
Journal Home Page Available: https://ijels.com/
Journal DOI: $10.22161 /$ ijels

Peer-Reviewed Journal

\title{
John Ruskin as a Social Reformer, and his views on Political Economy
}

\author{
Ms. K. Jancy ${ }^{1}$, Dr. V. Manimozhi ${ }^{2}$ \\ ${ }^{1}$ Assistant Professor, Department of English, Bharath Institute of Higher Education and Research, Chennai -600073, India \\ ${ }^{2}$ Professor, Department of English, Bharath Institute of Higher Education and Research, Chennai 600073, India
}

Received: 02 Jun 2021; Received in revised form: 01 Feb 2022; Accepted: 10 Feb 2022; Available online: 28 Feb 2022

C02022 The Author(s). Published by Infogain Publication. This is an open access article under the CC BY license

(https://creativecommons.org/licenses/by/4.0/).

\begin{abstract}
Ruskin born in 1819, he studied at seventeen and joined next year Christ College,Oxford, also good gentlemen. He was the foremost English art critic of the Victorian age. Ruskin convicts the science of political Economy as it makes no providing for social cares. Also it bases itself on the theory of utility, and which does not principal to this end and past its influence. It has striking and attractive piece like alchemy, astrology or witchcraft, but its reality is terrible and cold-hearted. The transmission of wealth in a public of nations can be associated to that of blood in the human body. The word discrimination consider as good or bad, depends on manner by which it is established and the purpose for used. Ruskin says from Dante's "Divine Comedy" means "You judges of the earth". What he mentioning that love and justice must be managerial values of political economy.
\end{abstract}

Keywords—astrology, discrimination, justice, Social reformer, Political economy.

\section{INDRODUCTION}

This paper has been explained about John Ruskin's political view and social aspects. Though he had more constructive his ideas were collective and stance. Ruskin was a man of powerful and inconsistency. Though he was educated at home, he impressed by his father's collection of watercolors and his mother's devout Protestantism. He was the central Victorian humanitarian but he believed a man who cannot find happiness himself and he can find from others.

\section{POLITICAL ECONOMY}

Orthodox political economy disregards social cares showing important but not fortuitous potentials. It may not interact with stark calamity, like assaults, impartiality and likings must pay the relations of leading and active, as in native service and the army. He mentioned that justice impart equal distribution of wealth. He admits that flawless impartiality cannot be recognized. The essential law says fundamental frugality is a clear desecration of the beliefs of Christianity.
According to Ruskin, honor belongs to those whose causes are directed by selflessness. If they are actuated by self-interest, they cannot be called honorable. Traders, therefore sincere to their consumers and operate even at the capital or life. No one can't buy happiness by using money, but it will definitely bring you a better class of emotions. Joyfulness having not in possessions, and not in precious things, happiness resides in the soul. Money, if it is not bring you happiness, will at least help you be depressed in comfort. Political economists emphasizing money. They do not stick importance to the development of social interactions. All business is running by money. They have understood very few law of mercantile economy. They rarely know the meaning of the word 'rich'. It is a relative word and implies its opposite 'poor'. The author says money power is always not perfect and uncertain.

We cannot achieve everything by money. Always morality greater than money, where money fails, morality shine brightly. The wealth of a country decides by the men and women goodness. Solomon's maxims on wealth demand a basis for justice. So, the information of 
righteousness and the rule of integrity are important. Always justice provides wealth better, and contracts its power in the attainment of superfluity. The affection of money which nurtures action of those who worship the Mammon. "A wise person always should have the money in their head, not in their heart"- Swift.

"Money is only a tool. It will take you wherever you wish, but it will not replace you as the driver" Price is exchange value articulated by moneys. The man has slop may exchange it for a cultivate. Then he gets an benefit but no yield. Today we could see many problems the cause money. People believe that money can do all things. Especially people who have worked in government sector they normally think they are settled in their life. Because they get fixed money in their life long. What others will do for their basic necessity. The government must thing about the low level people like farmers, daily wages and etc, The value of money is better than human value. Sometimes we are thinking or running behind money. But no matter whether we are having money or not. Many scholars saying wealth is important than money. If people accept this matter means there won't be problem in society.

\section{POLITICAL APPROACH}

Political economy approach is derivative from public choice theory on the one hand and fundamental political economics on the other hand.We may have many opinions about the political economy in different aspects. But the problems are how we are taking that matter or how we are dealing with that. All the problems dealt with substantial way and core of main issues. Every matter should be followed by authentic and informative. The thing which designed by the way of thinking it does not shows the human value instead it is saying their inner thinking. Every human has own interest their carrier and passion. But all the dreams may not come true. That moment may made everyone different state mind. Ruskin emphasizes the poverty, ignorance and oppression in a series of sermons. Also he adds many things like justice activates distribution of wealth in a better way.

Capital which means head or source or root material by which imitative well is fashioned. For example, a ploughshare is a general category of capital which issues in channels, which in turn, and will lead to the growth of corn. The purpose of capital is to increase life and not to reproduce itself. The political approach can be divided as two categories like traditional approach and modern approach. The traditional approach can be divided as legal approach, historical approach, philosophical approach, institutional approach. The traditional approach little connected with theory and research. This approach leads to more stresses towards the value of politics.

\section{CONCLUSION}

Ruskin used his own money for implementing many things in society. He identified the name of company Guild of Saint. George, the workers would run the business for wages also treated as fairly. So he argued with them should be run with waters not steam. Also he has concerned with ill effects with coal. He emphasized to the authorities collected money should be spent for the re-training for the workers or they must be get the another job. He concerned for the daily wages in factories. The Social Economist were telling about the professionals and executives received more money and keep top level, the middle class people are trying to get little bit lesser than top level people, the low level people trying and facing many issues.

"Quality is never an accident. It is always the result of intelligent effort".

"Judge a man by his questions rather than his answers".

"When love and skill work together, expect a masterpiece".

"There is no such thing as bad weather, only different kinds of good weather"

"There is hardly anything in the world that some man cannot make a little worse and sell a little cheaper, and the people who consider price only are this man's lawful prey".- John Ruskin

\section{REFERNCES}

[1] Cynthia Gamble, John Ruskin, Henry James and the Shropshire Lads (New European Publications, 2008) chapters 3-4.

[2] W. G. Collingwood, Life and Work of John Ruskin (Methuen, 1900) p. 402.

[3] Michael Brooks, John Ruskin and Victorian Architecture (Thames and Hudson, 1991), p. 127.

[4] John Ruskin's education. Infed.org. Retrieved 18 July 2017.

[5] Ruskin, John (1989). The Seven Lamps of Architecture. Dover Publications. p. 210

[6] For an illustrated history of Brantwood, see James S. Dearden, Brantwood: The Story of John Ruskin's Coniston Home (Ruskin Foundation, 2009). 